\title{
THE PORTUGUESE-SPEAKING WORLD
}

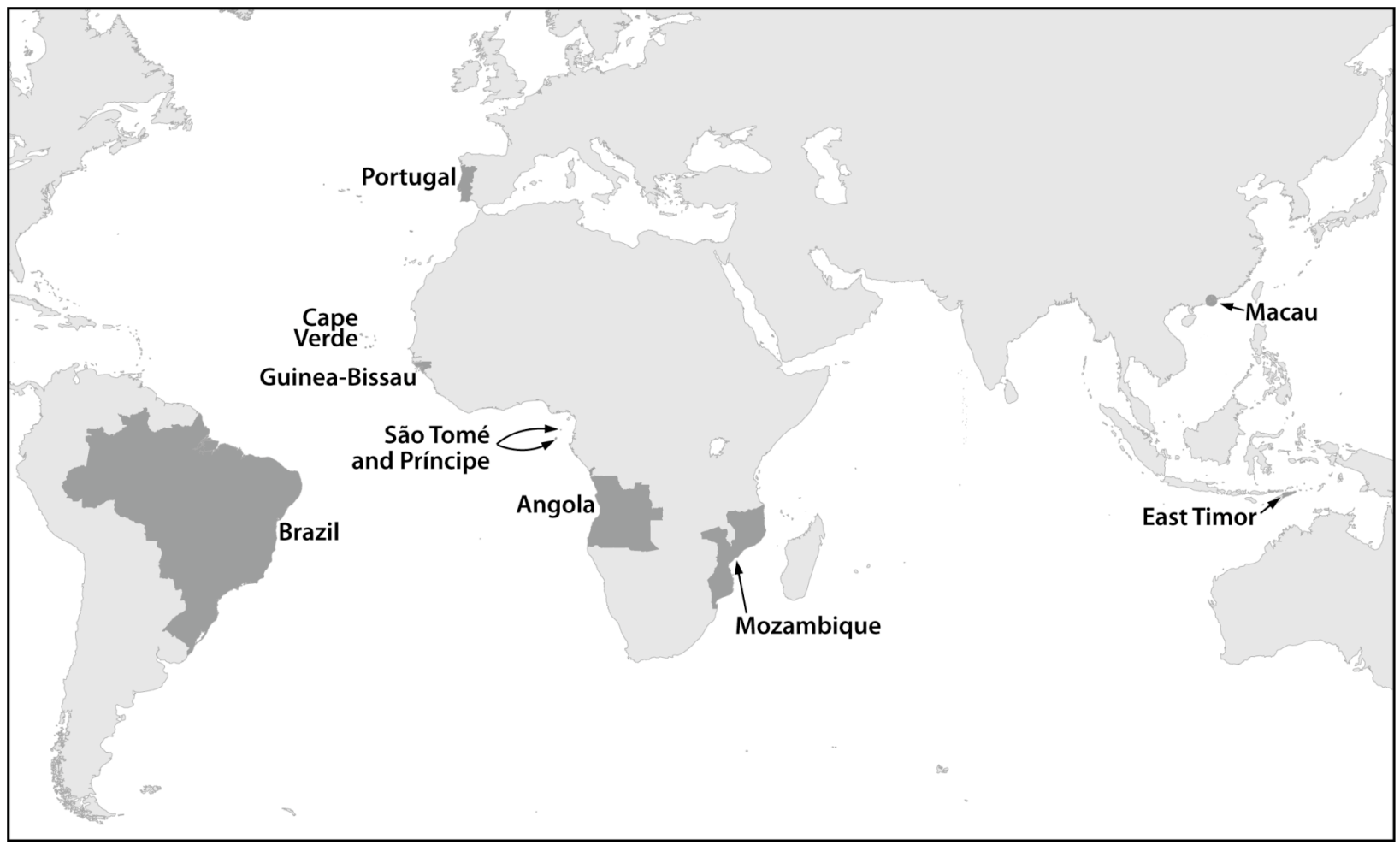


THIS PAGE INTENTIONALLY LEFT BLANK 